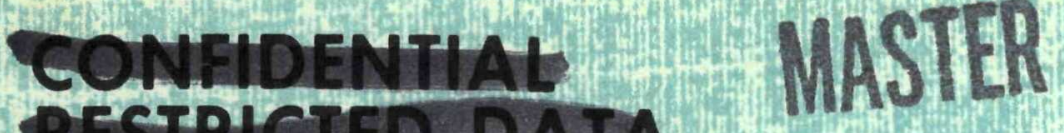

WANL - TME-1699

October 27, 1967

Subcontract NP-1

Westinghouse Astronuclear Laboratory

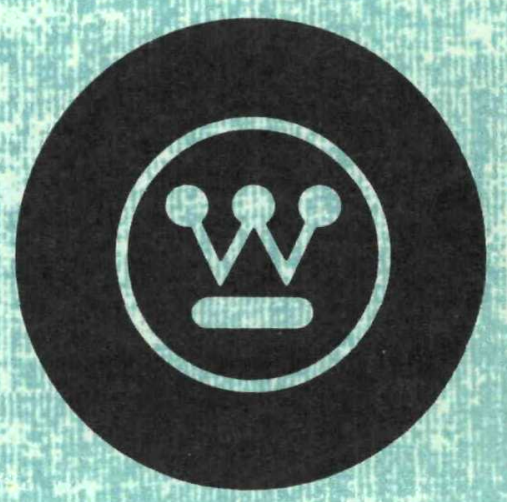

\title{
FINAL REPORT ON TEST SPECIFICATION III-4A REVERSE COATING (U)
}

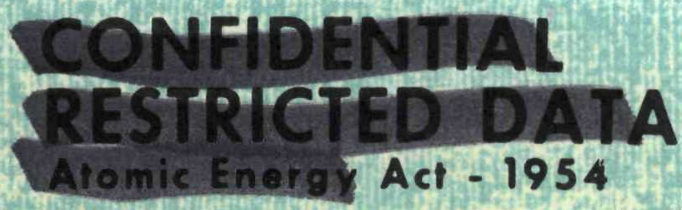




\section{DISCLAIMER}

This report was prepared as an account of work sponsored by an agency of the United States Government. Neither the United States Government nor any agency Thereof, nor any of their employees, makes any warranty, express or implied, or assumes any legal liability or responsibility for the accuracy, completeness, or usefulness of any information, apparatus, product, or process disclosed, or represents that its use would not infringe privately owned rights. Reference herein to any specific commercial product, process, or service by trade name, trademark, manufacturer, or otherwise does not necessarily constitute or imply its endorsement, recommendation, or favoring by the United States Government or any agency thereof. The views and opinions of authors expressed herein do not necessarily state or reflect those of the United States Government or any agency thereof. 


\section{DISCLAIMER}

Portions of this document may be illegible in electronic image products. Images are produced from the best available original document. 


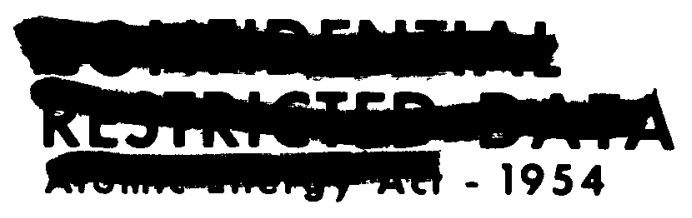

Subcontract NP-1

\section{MASTER}

WANL - TME - 1699

October 27,1967

\section{Westinghouse Astronuclear Laboratory}

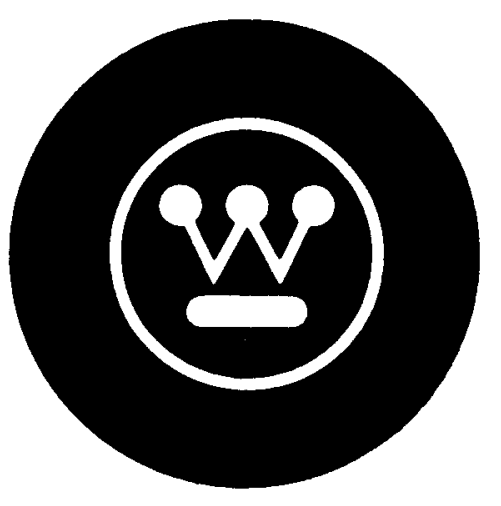

\section{FINAL REPORT ON TEST SPECIFICATION III-4A REVERSE COATING (U)}

This report was prepared as an account of work sponsored by the United States Government. Neither the United States nor the United States Energy Research and Development Administration, nor any of their employees, nor any of their contractors, subcontractors, or their employees, makes any warranty, express or implied, or assumes any legal liability or responsibility for the accuracy, completeness or usefulness of any information, apparatus, product or process disclosed, or represents that its use would not infringe privately owned rights.

Pavatur uy.

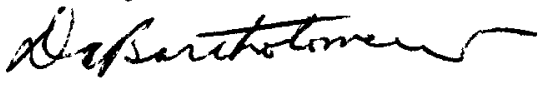

D. C. Bartholomew, Supervisor WNCO Coating Engineering

Approved by:

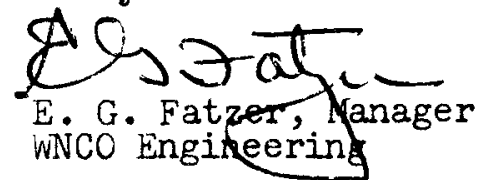

Approved by:

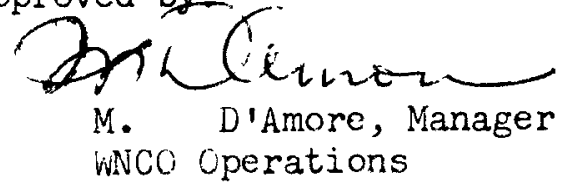

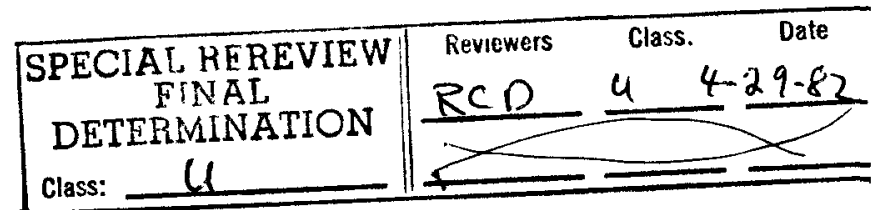
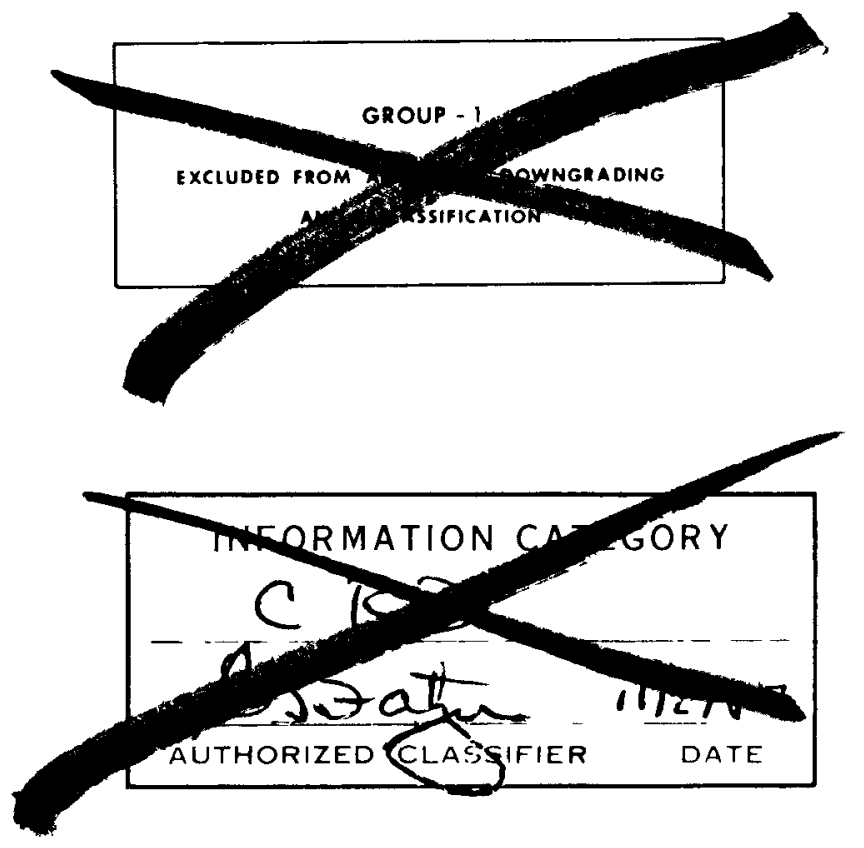

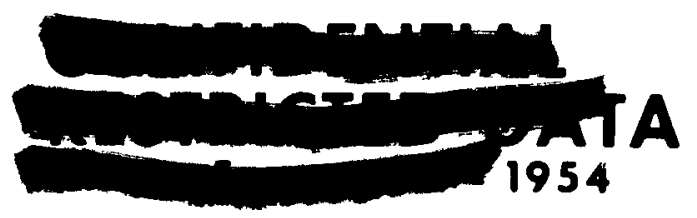


Act - $1 \longdiv { \text { This report was prepared as } }$ Notice

sponsored by the prepared as an account of work the United States nor States Government. Neither Research and Developor the United States Energy their employees, nor any subcontractors, or their any of their contractors, warranty, express or their employees, makes any liability or responsibility for the or assumes any legal or usefulness of any inform for accuracy, completeness process disclosed, or represents, apparatus, product or infringe privately owned rights.

\section{TABLE OF CONTENTS}

Section

INTRODUCTION

I. EXPERIMENTAL PLAN

II. DISCUSSION OF RESULTS

III.

CONCLUSIONS
$7-8$

\section{$\underline{\text { Page }}$}

$i-i i$

$1-2$

$2-7$
WANL-TME-1699

October 27, 1967

\section{ILLUSTRATIONS}

PHOTOMICROGRAPHS OF REPLICATED CHANNELS $\mathrm{L}-234$

PHOTOMICROGRAPHS OF REPLICATED CHANNELS $\mathbf{M}-77$

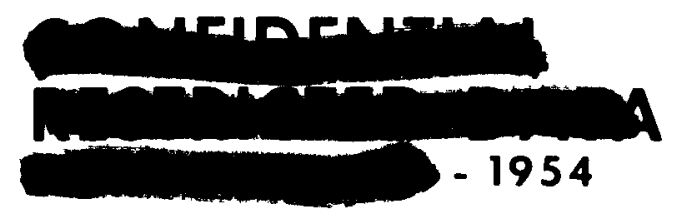




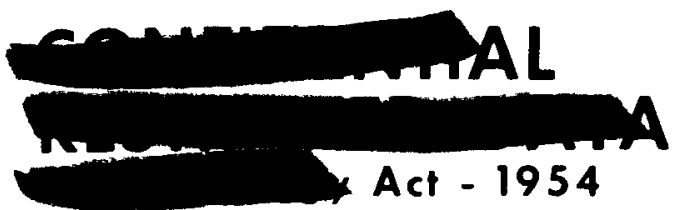

(2) Astronuclear

WANL-TME'-1699

October 27, 1967

\section{INTRODUCTION}

Ci. Since the NRX-A4 and NRX-A5 reactor tests indicated large cracks formed by high deposition temperatures and large differences between coating temperatures and reactor temperatures were detrimental to reactor performance, it was deemed advisable to attempt coating at temperatures which resembled reactor temperatures as nearly as possible.

(r) For this reason, it was proposed that the direction of gas during coating be reversed (serial numbered end to un-numbered end). Coating in this manner combined with generally lower temperatures would result in a better match of coating temperatures with reactor operating temperatures.

$U$ The primary objective of this Test Specification was to demonstrate the validity of this theory through a comparison of a run made in this manner versus one made using NRX-A6-1 coating parameters. The comparison and evaluation was to be made using the following criteria:

1. Dimensional Inspection

2. Non-Destructive Testing

3. Replication \& Photomicrography

4. Stoichiometry

5. Corrosion Testing 


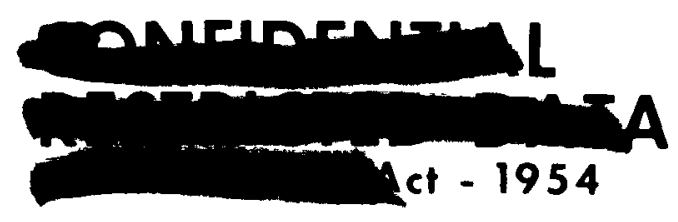

(20) Astronuclear

WANL-TME-1699

October 27, 1967

C... A secondary objective was to demonstrate the feasibility of a new fixture which permitted coating gases to enter the element in the "reverse" manner.

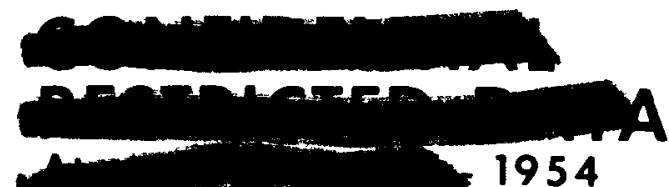




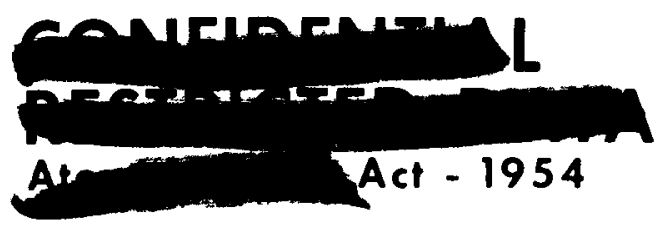

\section{(W. Astronuclear}

WANL-TME-1699

October 27, 1967

\section{EXPERIMENTAL PLAN}

Cras

Six WANL as-leached fuel elements made to the NRX-A6 drawing and containing NRX-A6 quality fuel beads were selected and placed in the reverse coat fixture with the serial numbered ends of the elements located at the top of the furnace. A sketch (Attachment A) illustrates the design features of the fixture. Note that both the bores and the O.D. of elements can be coated in a sequential manner using this fixture. Argon protects the $0 . D$. while coating the bores and vice versa.

The Run(L-237) was made using the following parameters. (The parameters for the NRX-A6-1 type run $((M-77))$ are shown for comparison.)

Run Time (Hours

Temperature, Un-numbered end $\left({ }^{\circ} \mathrm{C}\right)$

Temperature, mid-band of element $\left({ }^{\circ} \mathrm{C}\right)$

Temperature, serial numbered end $\left({ }^{\circ} \mathrm{C}\right)$

Flow, Argon (LPMPE)

Flow, HCL (LPMPE)
$\underline{L}-237$

14

1800

1600

1450

3.7

0.84
$\underline{M-77}$

8 1850 1963 2065

0.93

0.80

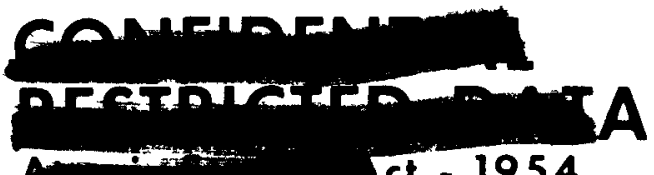




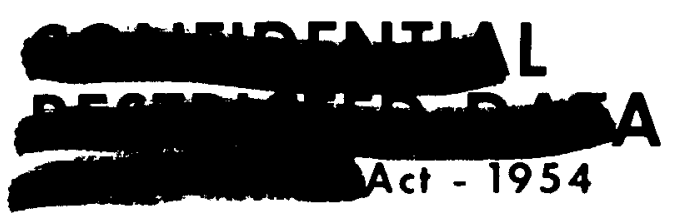

W Astronuclear

WANL-TME-1699

October 27, 1967

$\underline{L-237} \quad \underline{M-77}$

$\begin{array}{lll}\text { Flow, Hydrogen (LPMPE) } & 0.12 & 0.07\end{array}$

$\begin{array}{lll}\text { Flow, Salt (LPMPE) } & 0.11 & 0.07\end{array}$

Note the large difference in mid-band coating temperature.

U

The elements were then processed through Inspection and shipped

to WANHES for corrosion testing in accordance with the Test

Specification.

ser.

II. DISCUSSION OF RESULTS

CPD

The fuel elements in L-237 gained an average of 56.3 grams during coating while the $\mathrm{M}-77$ elements gained 75.8 grams.

s.

The coating thickness of the two runs as measured by the internal beta-backscatter technique was as follows:

COATING THICKNESS (MILS)

DISTANCE FROM S/N END (IN)

$\underline{\mathrm{L}-237} \quad \underline{\mathrm{M}-77}$

10

1.1

2.1

20

1.3

2.2

30

1.6

2.2

40

2.0

2.1

50

2.6

2.0

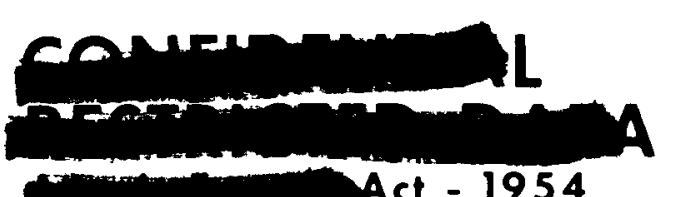




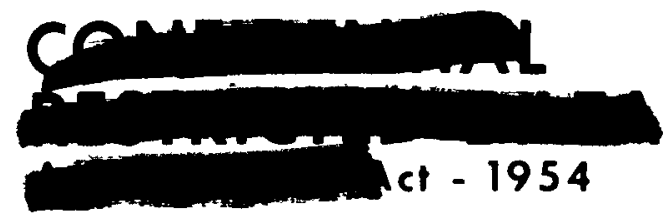

(W. Astronuclear

WANL-TME- 1699

October 27, 1967

CRD

The number of cracks per longitudinal inch of coating were counted using a binocular microscope. It was postulated that a higher number of cracks per inch would be desireable since the width of each crack would of necessity be less.

DISTANCE FROM S/N END (IN)

$$
16
$$

21

26

31

36

41
NO. OF CRACKS PER INCH Channel 11 $\underline{L-237}$ $\underline{M}-77$

60 8 9

39 7

34 9 32 11 38

Channels 10, 11 and 12 of an element from both muns were replicated using the pressurized/heated PVC tubing technique. Photos of these replicas at $20 "$ and $40 "$ from the $S / N$ end are shown as follows:

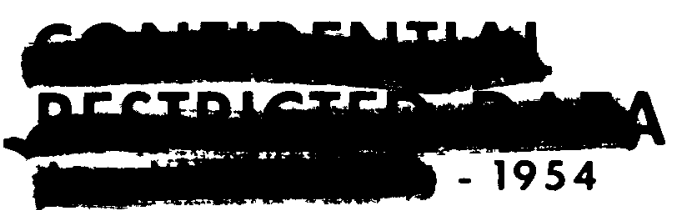




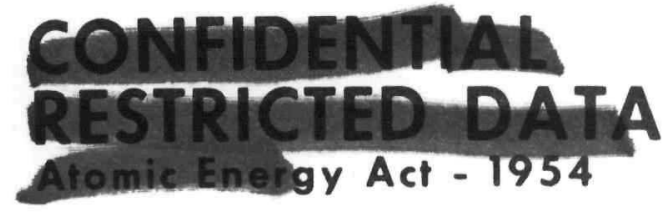

\section{(W) Astronuclear}

WANL-TME-1699

October 27, 1967

\section{PHOTOMICROGRAPHS OF REPLICATED CHANNELS}

\section{$\underline{L-237}$}

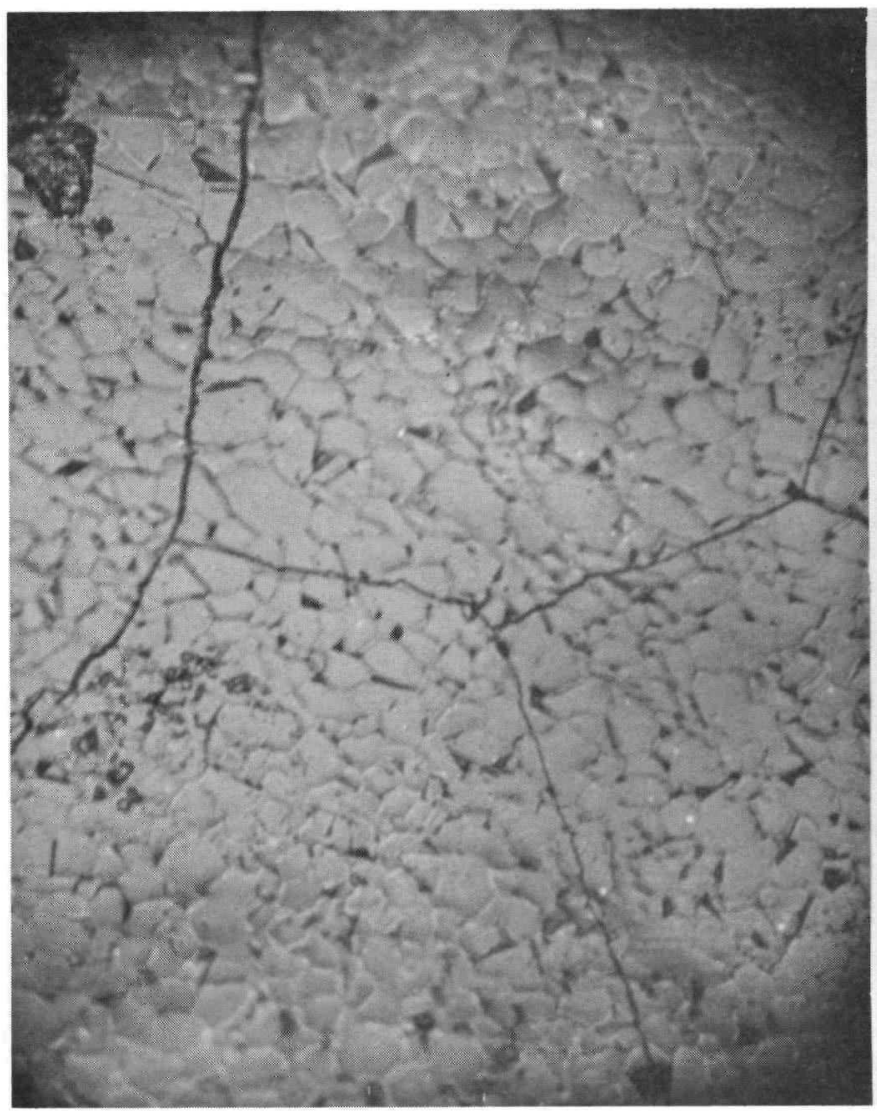

Element 39-32406 Channel 11 20" from Serial Number End

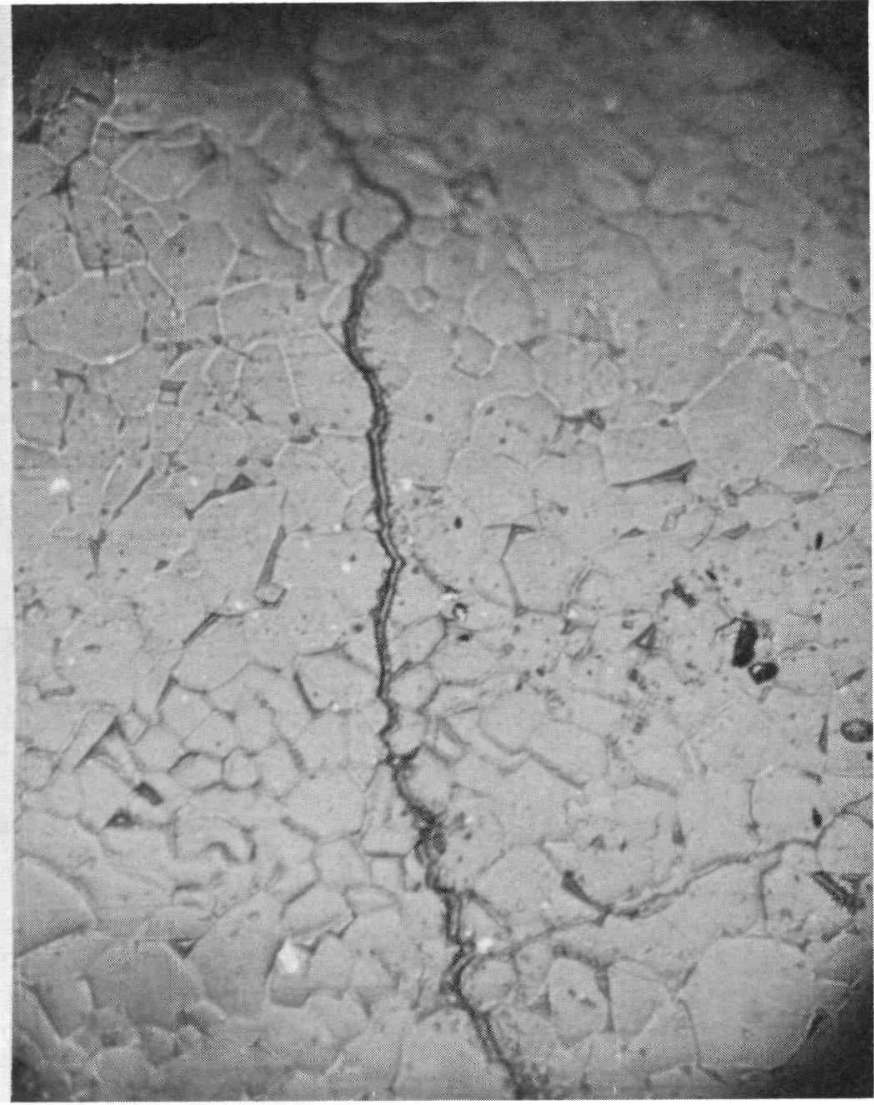

Element 39-32406 Channel 11 40" from Serial Number End

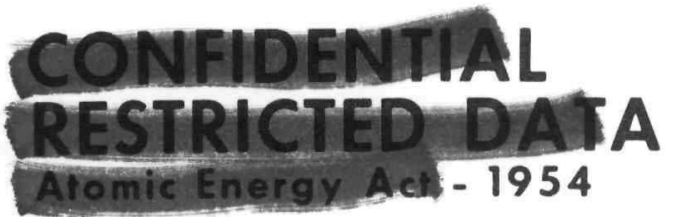




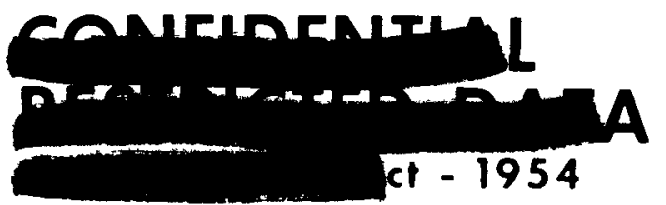

(2. Astronuclear

WANL-TME-1699

October 27,1967

Note the much narrower, more frequent cracks in the photos of L-237. Also note the presence of transgranular cracks in L-237. This is indicative of coatings with better adherence.

CRD The stoichiometry (Carbon/Niobium Ratio) of the bore coatings at $15^{\prime \prime}$ and 45" were measured for each of the runs via X-ray techniques. STOICHIOMETRY (C/NB)

\section{DISTANCE FROM S/N END (IN)}

14

45
$\underline{L-237}$

0.89

0.91

$\underline{\mathrm{M}-77}$

Not Avail.

After viewing the elements submitted for corrosion test, WANHES personnel determined that they could not be given a valid corrosion test. The reason for this opinion was the face that the exterior was coated for a distance of only $1 / 2^{\prime \prime}$. This was an insufficient length to protect the element from severe corrosion in the hotend chuck area.

CRD With respect to the secondary objective of the specification, the new design did not prove acceptable for coating elements with 3" long back coats. It should be pointed out, however, that the fixturing was originally designed for sequentially reverse coating the bores and the entire O.D. of elements, and for this purpose, it has proven to be acceptable.

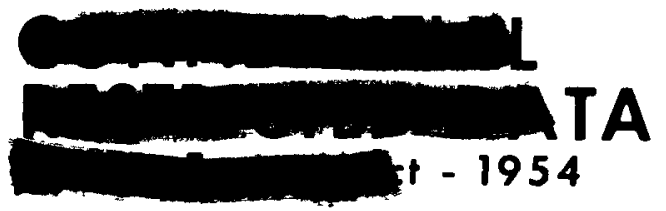




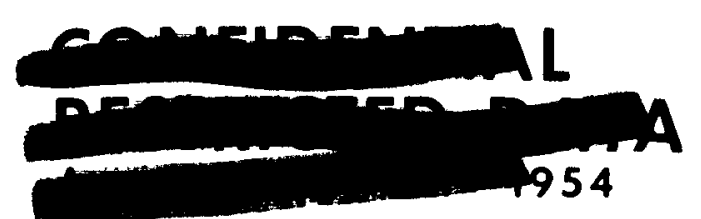

(We Astronuclear

WANL-TME-1699

October 27, 1967

\section{CONCLUSIONS}

CRD

The basic purpose of the Specification was to make a run in which the coating temperatures matched those of the reactor and demonstrate its superiority over previously used parameters.

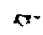

\section{$0:$}

Although it was impossible to validate the theory through a comparison or corrosion tests, photographic evidence of more adherent coatings with narrower room temperature cracks strongly suggests that the cracks would be narrower at operating temperatures if lower coating temperatures are used. With narrower cracks and better adherence at operating temperatures, an improvement in corrosion behavior should be observed.

$\operatorname{crs}$ It should be mentioned that although reversing the direction of coating gas improves the relationship of coating temperatures to operating temperatures, it is impossible to precisely match the reactor gradient due to furnace limitations. In addition, it would be impossible to deposit niobium carbide at the low temperatures observed near the entrance end of the reactor. For these reasons, it was decided to match the mid-band temperatures only. between:

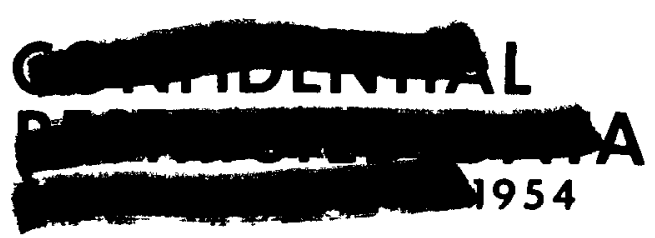




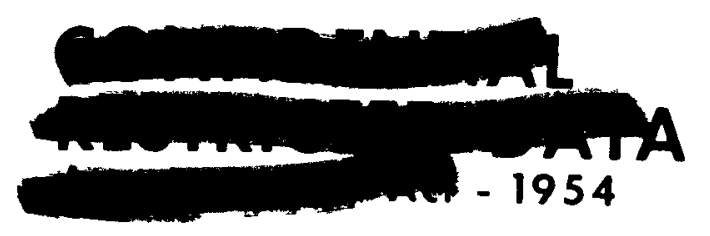

(W) Astronuclear

WANL-TME- 1699

October 27,1967

1. The intent of lower $S / N$ end-hotter un-numbered end coating temperatures.

2. The establishment of the desired coating thickness profile.

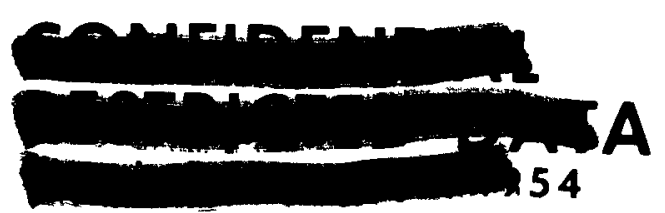




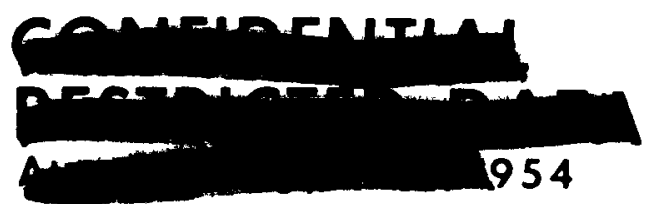

(W) Astronuclear

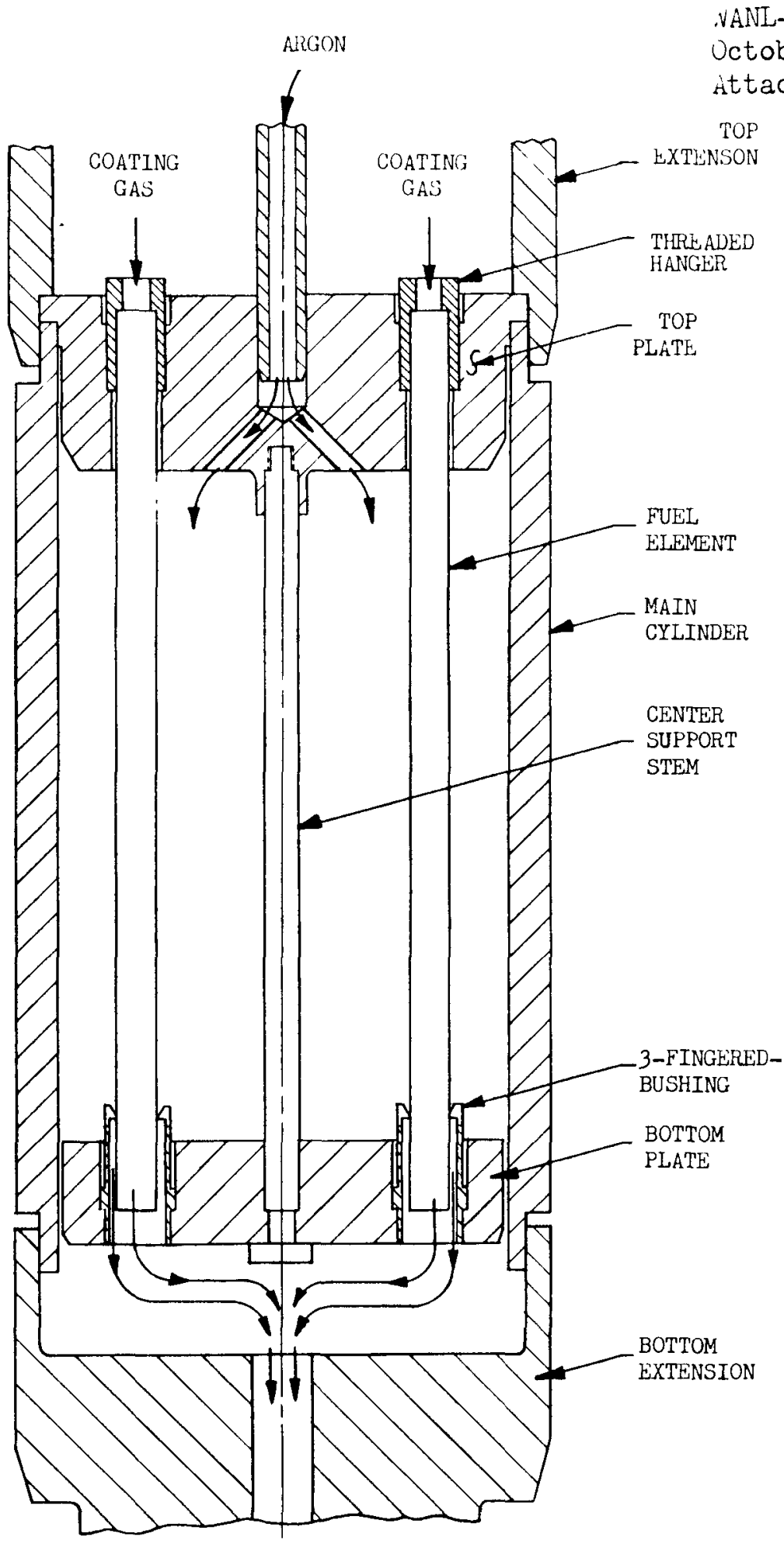

REVERSE COAT FIXTURE

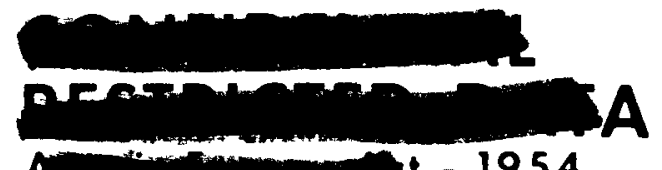




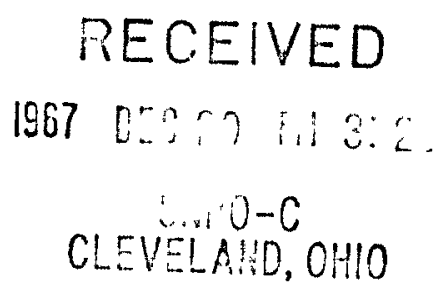

